\title{
INTRODUCTION TO THE SPECIAL ISSUE EFFECTIVE GOVERNANCE AS A NEW FORMULA FOR Public ACCOUNTABILITY
}

\author{
ANNA ŚLEDZIŃSKA-SIMON*, FRANS JORNA**
}

As the world tries to recover from a global financial crisis and the trust of citizens in their institutions is lower than ever, the question of effective governance is not merely an academic one ${ }^{1}$. In the face of unavoidable 'izations' - statization, constitutionalization, privatization and globalization, which occur consecutively or simultaneously across different contexts $^{2}$, it is pertinent to ask where the locus of authority is, or alternatively, where authority is transferred to, and where the locus of accountability lies. In this world, one thing is certain - the nation-state government is not effective enough to provide for all the needs of a society, and the term 'governance' signals two important developments that have a major impact on law and public policy: "1) government does not have a monopoly on public authority and resources; and 2) contemporary governments govern most effectively in concert with others"3.

Until now, effectiveness was usually related to outcomes - the impact of a government's programs on society - and efficiency measured the quality and quantity of goods and services provided by the government ${ }^{4}$. It seems, however, that effectiveness has come to entail much more than citizens'/clients' satisfaction and the attainment of a government's

\footnotetext{
DOI: $10.2478 /$ wrlae-2013-0049

* Assistant Professor, Constitutional Law Chair, Department of Law, Administration and Economy, University of Wroclaw, a.simon@prawo.uni.wroc.pl

** Professor of Governance, Saxion University of Applied Sciences, Enschede/Deventer, The Netherlands, f.b.a.jorna@saxion.nl

${ }^{1}$ Adrienne Heritier and Martin Rhodes (eds), New Modes of Governance in Europe: Governing in the Shadow of Hierarchy (Palgrave Macmillan 2011).

2 Judith Resnik, 'Globalization(s), privatization(s), constitutionalization, and statization: Icons and experiences of sovereignty in the 21st century' (2013) 11(1) International Journal of Constitutional Law 162-199.

${ }^{3}$ Allen Schick, 'OECD 50th Anniversary - Leveraged Governance: Avoiding Fracture and Getting Results' in OECD, Government at a Glance 2011 (OECD Publishing 2011).

${ }^{4}$ Allen Schick, 'The Performing State: Reflection on an Idea Whose Time Has Come but Whose Implementation Has Not' (2003) 3(2) OECD Journal on Budgeting 72-105.
} 
objectives. The 'old' concept of good governance seems to be shifting its orientation towards greater cost-sensitivity, power-sharing and participation. Moreover, an important element of efficient governance is the protection of rights, which means that rights must be taken into account in every policymaking process ${ }^{5}$. For example, in a recent decision of the Polish Constitutional Tribunal, the optimization of public employment could not prevail over guarantees of employment security for civil servants, notwithstanding clear advantages in the realm of public finance and improved effectiveness in the functioning of public administration. The Constitutional Tribunal held that the adopted measure did not adequately balance individual rights with the public interest, and was not based on clear statutory criteria ${ }^{6}$.

Notably, the language of public administration reform so prevalent in the first decade of the millennium has been replaced by a curious mix of normative approaches (focusing on integrity, public values and ethics), holistic systematic endeavours such as Open Government that do away with public-private and state-society dichotomies and offer non-hierarchical accounts of how society is structured in the information age, and fundamental needs-based accounts that push uncertainty, security, safety and risk to the fore, heralding the end of the state and making the case for urban free zones as the nuclei of global governance.

What do these three aspects have in common? For one thing, it is clear that they offer very different perspectives on public institutions than we have become used to in our modern states. They challenge traditional perspectives such as the bureaucratic nation-state or the Neo-Weberian state that have underpinned the formation of states. European public administration has altogether moved away from New Public Management as a dominant narrative and re-embraced public values, but it remains unclear what narrative is strong enough to underpin public institutions. We seem to know what we are moving away from, but do not yet clearly see the contours of what is to come.

One integrative perspective offered by a group of scholars led by Patrick Dunleavy focuses our attention on the impact of the information revolution. 'Digital era governance' comprises three core elements:

- reintegration (reversing the fragmentation of NPM across the publicprivate divide);

- needs-based holism: a thoroughgoing attempt to create clientfocused structures for departments and agencies to make public administration 'agile';

- digitalisation: covers the comprehensive adaptation of the public sector to completely embrace and imbed electronic delivery at the heart of the government business model, wherever possible ${ }^{7}$.

\footnotetext{
${ }^{5}$ For a human-rights approach in public policy see e.g. 'Guide for Local Planning from a Human Rights-Based Approach', United Nations Development Program (Argentina 2011).

${ }^{6}$ Judgment of 14 June 2011 concerning the Act on optimizing employment levels in state budget entities and in certain other entities of the public finance sector in the years 2011 2013, Case no Kp 1/11.

7 Patrick Dunleavy, Helen Margetts, Simon Bastow and Jane Tinkler, Digital Era Governance, IT Corporations, the State, and e-Government (Oxford University Press 2006) 227-228.
} 
A second effort to discern the rudiments of $21^{\text {st }}$-century public administration focuses on the functioning of democratic institutions, most notably on the concept of accountability ${ }^{8}$. Public accountability is both an instrument to achieve better public administration and a goal in itself. An actor is accountable to a given forum if he has the obligation to explain and justify his conduct, and the forum can ask questions, debate, pass judgments and impose sanctions. In this narrow approach, accountability strengthens the legitimacy of administrative actions. While there are certain accountability deficits at both the EU and Member State levels, European integration, though formally respecting the existing accountability arrangements in each member state, in effect greatly influences accountability. The Europeanization of many policy domains, the quest for European funds and the increasing influence of European accountability mechanisms (such as the European Commission's compliance procedures, the European Courts, the OLAF or the Court of Auditors review) has placed public accountability at the core of the functioning of European public administration.

We are experiencing a transformation of our public administration; this much is clear. What species and family will future public institutions belong to, then? More precisely: how do these trends and changes - the transformation of our democratic institutions and the information revolution - affect public administration? More precisely, how are its effectiveness and functioning impacted? Is the prevailing focus on effectiveness merely a change of nomenclature or maybe a paradigm shift?

The first set of articles focuses on the concept of information and the impact of the information revolution on the public sector. The analyses concern the effectiveness of information management, including new problems arising from the large-scale digitalization of information and data together with accuracy in evaluation of it, as well as access to public information and the right to re-use it.

The article by Charles Jeurgens describes challenges of the digital era related to the information flood and information loss. In particular, it analyses the appraisal and selection methods used by government institutions in the Netherlands from an archival perspective. Jeurgens argues that information runs institutions, as it is needed for policy making and policy implementation, but it also serves important social values such as civic participation, public accountability and transparency. He rightly remarks that the appraisal and selection of information are highly relevant in materializing the right to know, and more importantly, the capacity to know about government activities. Moreover, in the digital world, there is a pressing need to ensure the quality of available information and its effective oversight for the purposes of both retention and erasure, the costs of which are often underestimated. This brings him to the conclusion that selection in

\footnotetext{
${ }^{8}$ John Keane, The Life and Death of Democracy (Simons \& Schuster 2009); Mark Bovens, 'Two Concepts of Accountability: Accountability as a Virtue and as a Mechanism' (2011) 33(5) West European Politics 946-967; Mark Bovens, Robert E. Goodin and Thomas Schillemans (eds), The Oxford Handbook of Accountability (Oxford University Press 2014).
} 
a digital environment is a precondition for accessibility and appraisal, and that selection should be fully integrated into information and recordsmanagement processes.

The article by Mariusz Jabłoński attempts to assess the impact of the newly-amended Public Information Access Act that implements Directive 2003/98/EC of the European Parliament and the Council of 17 November 2003 on the re-use of public sector information in Poland. It presupposes that citizens availing themselves of the right to re-use public information for not only informational and control purposes, but also for tangible and intangible gains, will encourage both their democratic participation and economic activity. Jabłoński posits that the present model of public authority is based on greater involvement of citizens in various processes involving decision-making and co-governance, and that co-managing the common good along with relations between public authority and citizens are predetermined by the normative content of individual rights and freedoms.

In addition to problems related to archivization of government data and access to public information, effective governance faces problems related to the collection of information (data) and its accurate evaluation. Pieter Wagenaar et al. analyse the effects of closed circuit television (CCTV) on methods of surveillance, one of the core functions of government. They show how an abundance of data actually clouds the interpretation and critical reasoning that are so constitutive of administrative processes. Their case study carried out at Schiphold Airport in Amsterdam demonstrates that the use of CCTV may lead to a loss of 'sense-making' when officials forget or are made to forget the multitude of interpretative possibilities of social reality, substituting plausibility with the mirage of accuracy.

The second set of articles focuses on accountability and the way in which this notion is being transformed. Dawid Sześciło's article deals with market-like values in public administration. He offers a historical overview of the development of market-based arrangements in public service delivery such as outsourcing of public services, public-private partnerships and vouchers at the local government level in Poland. Sześciło notes that the existing legislative framework allows the outsourcing of public services falling within the scope of municipal tasks and the establishment of publicprivate partnership projects for the realization of municipal tasks. In the absence of comparative research on the effectiveness of market mechanisms vis-à-vis the in-house model of public service delivery, any planned expansion of such mechanisms should be preceded by a comprehensive evaluation of their outcomes and outputs.

Frans Jorna compares various trends in urban governance over the last twenty years in Almelo (The Netherlands), Potsdam (Germany) and Wroclaw (Poland), characterizing them as Participative Urban Governance (PUG). He shows how local public-social relations are better defined through concepts that are more inclusive and horizontal than that of 'government', and argues that the normative attraction of this shift from topdown government to participative governance lies in the promise to optimize autonomy, cooperation and capabilities. At the same time, Jorna observes that horizontalization has seriously eroded local governments' position in the social domain. In conclusion, Jorna finds that the future of 
local democracy lies not in improving the effectiveness of municipal administration per se, but in improving accountability as a condition for vitality and return-on-investment.

The contributions in this issue do not attempt to re-define the concept of governance, nor to replace existing descriptors of governance ('good', 'new', 'multi-level' etc.) with a new adjective ('effective'). They rather understand governance as a framework concept with a plurality of meanings, and point to new challenges, tendencies and transformations that highlight what is essential within this concept. While effectiveness has been always a constitutive element of governance, effective governance emphasizes that effectiveness may be not only a method of policy implementation, but a goal in itself. More importantly, it is not only descriptive, but also normative in that it prescribes certain conditions of effectiveness such as cost- and rights-awareness.

The two integrative approaches presented in this volume have much in common and lead us to recall the essential elements of accountability: officials called to account; a forum; a means being employed; yardsticks and values being applied; and the re causa itself - the behaviour that is being accounted for. The articles demonstrate that evaluating effectiveness starts by designing the process for doing so, and that this in itself is a normative endeavour where the answer to the question of what information is evaluated by whom in what way is telling of the way we conceptualize terms like 'public', 'authority' and 'government'. They also show us that it is advisable and possible to combine a normative approach with solid empirical research. As such, we hope to contribute not only to the Polish and European debate on accountability, but also provide a valuable contribution to the practitioners' debate on effective governance and accountability. 